\title{
Layer-Specific Input to Distinct Cell Types in Layer 6 of Monkey Primary Visual Cortex
}

\author{
Farran Briggs and Edward M. Callaway \\ Systems Neurobiology Laboratories, Salk Institute for Biological Sciences and Department of Biology, University of \\ California, San Diego, La Jolla, California 92037
}

Layer 6 of monkey V1 contains a physiologically and anatomically diverse population of excitatory pyramidal neurons. Distinctive arborization patterns of axons and dendrites within the functionally specialized cortical layers define eight types of layer 6 pyramidal neurons and suggest unique information processing roles for each cell type. To address how input sources contribute to cellular function, we examined the laminar sources of functional excitatory input onto individual layer 6 pyramidal neurons using scanning laser photostimulation. We find that excitatory input sources correlate with cell type. Class I neurons with axonal arbors selectively targeting magnocellular (M) recipient layer $4 \mathrm{C} \alpha$ receive input from $\mathrm{M}$-dominated layer $4 \mathrm{~B}$, whereas class I neurons whose axonal arbors target parvocellular (P) recipient layer $4 \mathrm{C} \beta$ receive input from
P-dominated layer 2/3. Surprisingly, these neuronal types do not differ significantly in the inputs they receive directly from layers $4 \mathrm{C} \alpha$ or $4 \mathrm{C} \beta$. Class II cells, which lack dense axonal arbors within layer $4 \mathrm{C}$, receive excitatory input from layers targeted by their local axons. Specifically, type IIA cells project axons to and receive input from the deep but not superficial layers. Type IIB neurons project to and receive input from the deepest and most superficial, but not middle layers. Type IIC neurons arborize throughout the cortical layers and tend to receive inputs from all cortical layers. These observations have implications for the functional roles of different layer 6 cell types in visual information processing.

Key words: macaque; visual cortex; V1; layer 6; photostimulation; excitatory input; local circuits; caged glutamate
Layer 6 of monkey primary visual cortex, or V1, contains a morphologically and functionally diverse population of pyramidal neurons (Hubel and Wiesel, 1968; Lund and Boothe, 1975; Hawken et al., 1988; Wiser and Callaway, 1996). Each distinct, anatomically defined cell type is hypothesized to play a unique role in visual information processing (Wiser and Callaway, 1996, 1997; Callaway, 1998). Intracellular labeling studies reveal two classes of layer 6 pyramidal neuron (Wiser and Callaway, 1996). Class I neurons are characterized by dense axonal and dendritic arborizations within the lateral geniculate nucleus (LGN) recipient layer 4C. Five class I cell types are defined by distinct axonal/dendritic locations within the magnocellular (M) and parvocellular (P) LGN-recipient subdivisions of layer 4C (Fig. 1, top row). Two cell types, $\mathrm{I} \alpha$ and $\mathrm{Im}$, arborize specifically in the M-recipient layer 4C $\alpha$ (Wiser and Callaway, 1996), suggesting roles in circuits related to visual motion processing (Lund and Boothe, 1975) (for review, see Livingstone and Hubel, 1988; Merigan and Maunsell, 1993; Callaway, 1998). I $\beta$ and I $\beta$ A cell types arborize in the P-recipient layer $4 \mathrm{C} \beta$, suggesting roles related to shape or color processing. Type IC neurons arborize in both M- and P-recipient layers. Anatomical relationships between the dendrites of class I cells and axons of cells in other layers suggest that class I cells should receive input from the same

Received Dec. 8, 2000; revised March 5, 2001; accepted March 7, 2001.

This work was supported by National Institutes of Health Grant EY10742, National Institutes of Health Training Grant T32 GM08107-15 (F.B.), and the Chapman Charitable Trust (F.B.). We thank Jami Dantzker and Dr. Atomu Sawatari for technical and programming assistance, Soumya Chatterjee, and Drs. Amy Butler, Greg Horwitz, and Ed Lein for helpful comments on the manuscript, and Sandra Tye for assistance with animals.

Correspondence should be addressed to Farran Briggs, Systems Neurobiology Laboratories-C, Salk Institute for Biological Sciences, 10010 North Torrey Pines Road, La Jolla, CA 92037. E-mail: fbriggs@biomail.ucsd.edu.

Copyright @ $\odot 2001$ Society for Neuroscience $0270-6474 / 01 / 213600-09 \$ 15.00 / 0$ subdivision or subdivisions of layer $4 \mathrm{C}$ targeted by their local axons, consistent with participation in direct feedback circuits (Callaway, 1998).

Class II neurons avoid arborizing in layer $4 \mathrm{C}$ and instead extend axons to deep and/or more superficial cortical layers (Fig. 1 , bottom row). They also differ from class I cells by having more extensive dendritic arbors in layer 5, suggesting they are more likely to receive input from superficial layer neurons (Blasdel et al., 1985; Fitzpatrick et al., 1985; Lachica et al., 1992; Callaway and Wiser, 1996). These anatomical relationships suggest that class II neurons play roles in feedback circuits involving the deepest and most superficial layers rather than layer 4C (Callaway, 1998).

Close examination of the anatomy of each layer 6 cell type reveals that each layer 6 pyramidal neuron could receive input from any cortical layer. This observation illustrates the necessity of an assay of functional connections to discriminate the individual input patterns for each cell type (Sawatari and Callaway, 1996, 2000; Dantzker and Callaway, 2000; Yabuta et al., 2001). To identify functional connectivity, we used scanning laser photostimulation and whole-cell voltage-clamp recording to assay the laminar sources of functional excitatory input onto each type of layer 6 pyramidal neuron (Callaway and Katz, 1993; Katz and Dalva, 1994; Sawatari and Callaway, 1996, 2000; Dantzker and Callaway, 2000; Yabuta et al., 2001).

We discovered that different layer 6 pyramidal cell types receive different patterns of laminar input. Class II cells receive excitatory input from the layers targeted by their axons, consistent with the prediction that these cells provide direct feedback to those layers providing their input. Unexpectedly, class I cells did not receive specific inputs from the layer $4 \mathrm{C}$ subdivisions targeted by their axons. Specific inputs arose instead from superficial 


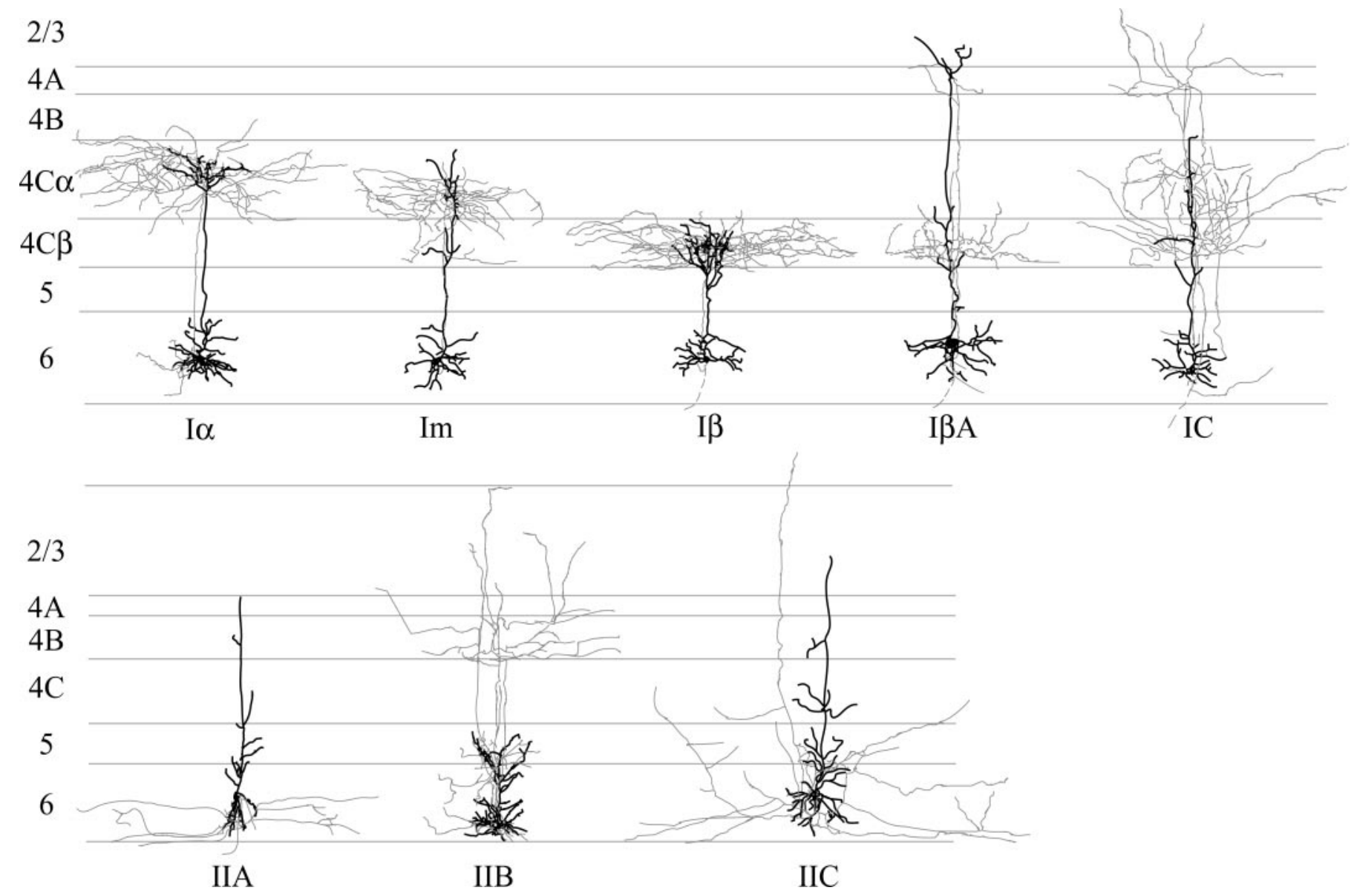

Figure 1. Eight anatomical types of layer 6 pyramidal neurons in monkey V1. Cell type is labeled beneath each reconstruction. Dendrites are black, and axons are gray. Axons extending below layer 6 indicate cell types that sometimes (dashed lines) or always (solid lines) project out of V1. Laminar borders are depicted by the horizontal lines and labeled to the left of each row. Class I neurons are in the top row, and class II neurons are in the bottom row. Most cells shown are from Wiser and Callaway (1996), their Fig. 12. Camera lucida drawings were modified to allow accurate depictions of laminar specificity in the context of idealized, width-invariant cortical layers.

cortical layers. M-dominated layer 4B, which receives its strongest input from layer 4C $\alpha$ (Fitzpatrick et al., 1985; Lachica et al., 1992; Yoshioka et al., 1994; Yabuta and Callaway, 1998b), provides strong excitatory input to class I cells whose axons target layer 4C $\alpha$. P-dominated layer $2 / 3$, which receives its strongest input from layer 4C $\beta$ (Blasdel et al., 1985; Fitzpatrick et al., 1985; Lachica et al., 1992; Yoshioka et al., 1994; Yabuta and Callaway, 1998b), provides strong excitatory input to class I cells whose axons target layer $4 \mathrm{C} \beta$.

\section{MATERIALS AND METHODS}

Laser-scanning photostimulation was used to map laminar sources of excitatory input to layer 6 pyramidal neurons in living V1 brain slices prepared from macaque monkeys. V1 tissue was collected from the opercular cortical surface and brain slices were prepared from seven juvenile (19-24 months old) macaque monkeys (four Macaca mulatta, three Macaca radiata) of both sexes. For some animals, tissue was collected on two separate days. In this case, a recovery surgery was performed to collect tissue from one cortical hemisphere on the first experimental day, followed 5-10 d later with an identical nonrecovery surgery to collect tissue from the second hemisphere (Sawatari and Callaway, 2000). On average, 10 cells were recorded per animal, of which an average of six yielded data for layer 6 cells analyzed in this study. Additional brain slices from the same animals were used for other studies. Details of the preparation of living brain slices from monkeys have been described previously (Callaway and Wiser, 1996; Wiser and Callaway, 1996; Sawatari and Callaway, 2000). All procedures were approved by the Institutional Animal Care and Use Committee.
Local stimulation of presynaptic input neurons by light-evoked conversion of caged glutamate to glutamate (photostimulation) was used to map laminar sources of functional connections onto individual recorded neurons (Callaway and Katz, 1993; Katz and Dalva, 1994; Sawatari and Callaway, 1996, 2000; Dantzker and Callaway, 2000). The methods used to collect data in this study were described in detail by Sawatari and Callaway (2000). Briefly, a 400- $\mu$ m-thick coronal or sagittal brain slice was transferred from an interface holding chamber and submerged in a recording chamber containing room temperature, oxygenated ACSF with $150 \mu \mathrm{M} \alpha$-CNB caged glutamate [ $\gamma$-(2-carboxy-2-nitrobenzyl) ester, trifluoroacetic acid salt; G-7055; Molecular Probes, Eugene, OR]. Using an 8-12 $\mathrm{M} \Omega$ resistance glass microelectrode filled with potassium gluconate-based intracellular solution containing $0.5 \%$ biocytin, a single neuron in layer 6 of V1 was whole-cell patched, voltage-clamped at -65 $\mathrm{mV}$, and inward, EPSCs were measured. UV light from an argon-ion laser, focused through a $40 \times$ microscope objective into the brain slice, was used to photostimulate discrete sites in the slice. Two different microscope set-ups were used for photostimulation in this study. In the first set-up, laser light was focused through an oil-immersion objective mounted on a set of motorized stages below the recording chamber (Sawatari and Callaway, 1996). The second set-up used a DIC microscope with the UV light focused through a water-immersion objective onto the top of the brain slice (Sawatari and Callaway, 2000). The laser power output was adjusted such that the amount of UV light reaching the brain slice was the same for both set-ups. Photostimulation involved flashing the UV light for $10 \mathrm{msec}$, causing uncaging of glutamate at the focal point of the objective. Control experiments (photostimulation during current-clamp recording) reveal that these stimulation parameters result in action potential generation only in neurons with somata within $50-75 \mu \mathrm{m}$ of the stimulation site (Sawatari and Callaway, 2000). Control 


\begin{tabular}{|c|c|c|c|c|c|c|c|c|c|}
\hline Cell Type & Cell Name & $2 / 3$ & $4 \mathrm{~A}$ & $4 \mathrm{~B}$ & $4 \mathrm{C}$ & $4 \mathrm{C} \alpha$ & $4 \mathrm{C} \beta$ & 5 & 6 \\
\hline $\operatorname{Im}$ & B48c16 & & & $\mathrm{a}$ & $\mathrm{a}, \mathrm{n}, \mathrm{s}$ & $\mathrm{a}, \mathrm{n}, \mathrm{s}$ & $\mathrm{a}, \mathrm{n}, \mathrm{s}$ & $\mathrm{a}, \mathrm{n}, \mathrm{s}$ & $\mathrm{a}, \mathrm{n}, \mathrm{s}$ \\
\hline $\mathrm{I} \alpha$ or $\mathrm{Im}$ & B44c6 & & $\mathrm{a}$ & & $\mathrm{a}$ & & $\mathrm{a}$ & & $\mathrm{n}, \mathrm{s}$ \\
\hline $\mathrm{I} \alpha$ & $\mathrm{B} 48 \mathrm{c} 3$ & & & $\mathrm{n}, \mathrm{s}$ & & & & $\mathrm{a}$ & \\
\hline $\mathrm{I} \alpha$ & A46c1 & & & & $\mathrm{a}$ & & $\mathrm{a}$ & $\mathrm{n}, \mathrm{s}$ & \\
\hline $\mathrm{I} \alpha$ & $\mathrm{A} 46 \mathrm{c} 7$ & & $\mathrm{a}$ & $\mathrm{a}$ & & & & & \\
\hline$I \alpha$ & $B 48 c 11$ & & & $\mathrm{a}, \mathrm{n}, \mathrm{s}$ & $\mathrm{a}, \mathrm{n}, \mathrm{s}$ & $\mathrm{a}, \mathrm{n}, \mathrm{s}$ & $\mathrm{a}, \mathrm{n}, \mathrm{s}$ & $\mathrm{a}, \mathrm{n}, \mathrm{s}$ & $\mathrm{a}, \mathrm{n}, \mathrm{s}$ \\
\hline IC & $\mathrm{A} 46 \mathrm{c} 5$ & & & & $\mathrm{a}$ & $\mathrm{a}$ & & $\mathrm{a}, \mathrm{s}$ & $\mathrm{a}, \mathrm{n}, \mathrm{s}$ \\
\hline IC & A $47 \mathrm{c} 5$ & $\mathrm{n}, \mathrm{s}$ & & & $\mathrm{a}, \mathrm{n}, \mathrm{s}$ & $\mathrm{n}, \mathrm{s}$ & $\mathrm{a}, \mathrm{n}, \mathrm{s}$ & $\mathrm{n}, \mathrm{s}$ & $\mathrm{a}, \mathrm{n}, \mathrm{s}$ \\
\hline IC & $\mathrm{B} 42 \mathrm{c} 5$ & & & & & & & $\mathrm{a}, \mathrm{n}, \mathrm{s}$ & $\mathrm{a}, \mathrm{n}, \mathrm{s}$ \\
\hline$I C$ & $A 48 c 1$ & $\mathrm{n}, \mathrm{s}$ & & & & & & $\mathrm{a}, \mathrm{n}, \mathrm{s}$ & $\mathrm{n}, \mathrm{s}$ \\
\hline $\mathrm{I} \beta$ & $\mathrm{A} 45 \mathrm{c} 1$ & $\mathrm{a}, \mathrm{n}, \mathrm{s}$ & & & & & & & $\mathrm{a}$ \\
\hline $\mathrm{I} \beta$ or $\mathrm{I} \beta \mathrm{A}$ & A48c11 & & & & $\mathrm{a}, \mathrm{n}, \mathrm{s}$ & & $\mathrm{a}, \mathrm{n}, \mathrm{s}$ & $\mathrm{a}, \mathrm{n}, \mathrm{s}$ & \\
\hline $\mathrm{I} \beta$ & B46c7 & & & & $\mathrm{a}$ & & $\mathrm{a}$ & $\mathrm{n}, \mathrm{s}$ & $\mathrm{a}$ \\
\hline$I \beta$ & $B 48 c 2$ & $\mathrm{a}, \mathrm{n}, \mathrm{s}$ & & & $\mathrm{a}, \mathrm{n}, \mathrm{s}$ & $\mathrm{a}, \mathrm{n}, \mathrm{s}$ & $\mathrm{a}, \mathrm{n}, \mathrm{s}$ & $\mathrm{a}, \mathrm{n}, \mathrm{s}$ & $\mathrm{a}, \mathrm{n}, \mathrm{s}$ \\
\hline $\mathrm{I} \beta \mathrm{A}$ & $\mathrm{B} 43 \mathrm{c} 5$ & & & & $\mathrm{n}, \mathrm{s}$ & & $\mathrm{n}, \mathrm{s}$ & & \\
\hline $\mathrm{I} \beta \mathrm{A}$ & $\mathrm{B} 47 \mathrm{c} 3$ & $\mathrm{n}, \mathrm{s}$ & & & $\mathrm{n}, \mathrm{s}$ & $\mathrm{n}, \mathrm{s}$ & & $\mathrm{n}, \mathrm{s}$ & $\mathrm{n}, \mathrm{s}$ \\
\hline $\mathrm{I} \beta \mathrm{A}$ & B43c4 & $\mathrm{a}$ & & & $\mathrm{a}, \mathrm{n}, \mathrm{s}$ & & $\mathrm{s}$ & $\mathrm{a}$ & \\
\hline $\mathrm{I} \beta \mathrm{A}$ & A $43 \mathrm{c} 5$ & & & & $\mathrm{a}$ & & $\mathrm{a}$ & & $\mathrm{n}, \mathrm{s}$ \\
\hline $\mathrm{I} \beta \mathrm{A}$ & $\mathrm{B} 47 \mathrm{c} 2$ & & & $\mathrm{n}, \mathrm{s}$ & $\mathrm{n}, \mathrm{s}$ & $\mathrm{n}, \mathrm{s}$ & $\mathrm{n}, \mathrm{s}$ & $\mathrm{n}, \mathrm{s}$ & $\mathrm{n}, \mathrm{s}$ \\
\hline $\mathrm{I} \beta \mathrm{A}$ & $\mathrm{B} 47 \mathrm{c} 1$ & $\mathrm{a}, \mathrm{n}, \mathrm{s}$ & & & $\mathrm{a}, \mathrm{n}, \mathrm{s}$ & $\mathrm{a}, \mathrm{n}, \mathrm{s}$ & $\mathrm{a}, \mathrm{n}, \mathrm{s}$ & $\mathrm{a}, \mathrm{n}, \mathrm{s}$ & (not stim) \\
\hline $\mathrm{I} \beta \mathrm{A}$ & A43c6 & $\mathrm{a}$ & & & $\mathrm{a}$ & & $\mathrm{a}$ & $\mathrm{a}$ & \\
\hline IIA & B44c2 & $\mathrm{a}$ & & & $\mathrm{a}$ & $\mathrm{a}$ & & & \\
\hline IIA & $\mathrm{A} 47 \mathrm{c} 4$ & & & & & & & $\mathrm{a}, \mathrm{n}, \mathrm{s}$ & $\mathrm{a}, \mathrm{n}, \mathrm{s}$ \\
\hline$I I A$ & $A 48 c 12$ & & & & $\mathrm{a}, \mathrm{n}, \mathrm{s}$ & $\mathrm{a}, \mathrm{s}$ & $\mathrm{a}, \mathrm{n}, \mathrm{s}$ & $\mathrm{a}, \mathrm{n}, \mathrm{s}$ & $\mathrm{a}$ \\
\hline IIA & $\mathrm{A} 45 \mathrm{c} 8$ & & & & $\mathrm{a}$ & $\mathrm{a}$ & & $\mathrm{s}$ & \\
\hline IIA & A46c6 & & & a & $\mathrm{n}, \mathrm{s}$ & & & & $\mathrm{n}, \mathrm{s}$ \\
\hline IIB & $\mathrm{B} 44 \mathrm{c} 8$ & $\mathrm{a}, \mathrm{n}, \mathrm{s}$ & & $\mathrm{a}$ & & & & & \\
\hline IIB & $\mathrm{A} 45 \mathrm{c} 2$ & $\mathrm{a}$ & & & & & & $\mathrm{a}$ & $\mathrm{a}$ \\
\hline IIB & $\mathrm{A} 45 \mathrm{c} 4$ & $\mathrm{a}$ & & & $\mathrm{a}$ & & $\mathrm{a}$ & $\mathrm{a}, \mathrm{n}, \mathrm{s}$ & $\mathrm{a}, \mathrm{n}, \mathrm{s}$ \\
\hline$I I B$ & $B 45 c 7$ & $\mathrm{a}$ & & & & & & & \\
\hline IIB & $\mathrm{A} 44 \mathrm{c} 2$ & $\mathrm{a}$ & & & $\mathrm{a}$ & & $\mathrm{a}$ & & $\mathrm{a}$ \\
\hline IIB & A $45 \mathrm{c} 3$ & $\mathrm{a}$ & & & $\mathrm{a}$ & & $\mathrm{a}$ & & \\
\hline IIB & B $45 \mathrm{c} 6$ & & & & & & & $\mathrm{n}, \mathrm{s}$ & $\mathrm{n}, \mathrm{s}$ \\
\hline IIB & $\mathrm{B} 48 \mathrm{c} 1$ & $\mathrm{n}, \mathrm{s}$ & & $\mathrm{n}, \mathrm{s}$ & $\mathrm{a}, \mathrm{n}, \mathrm{s}$ & & $\mathrm{a}, \mathrm{n}, \mathrm{s}$ & $\mathrm{a}, \mathrm{n}, \mathrm{s}$ & $\mathrm{a}, \mathrm{n}, \mathrm{s}$ \\
\hline$I I C$ & $A 43 c 4$ & $\mathrm{a}$ & $\mathrm{n}, \mathrm{s}$ & $\mathrm{n}, \mathrm{s}$ & $\mathrm{a}, \mathrm{n}, \mathrm{s}$ & $\mathrm{a}$ & $\mathrm{a}, \mathrm{n}, \mathrm{s}$ & $\mathrm{a}$ & \\
\hline IIC & $\mathrm{B} 45 \mathrm{c} 3$ & $\mathrm{a}, \mathrm{n}, \mathrm{s}$ & & & & & & $\mathrm{a}$ & $\mathrm{a}$ \\
\hline IIC & $\mathrm{B} 45 \mathrm{c} 8$ & & & & & & & $\mathrm{a}$ & \\
\hline IIC & $\mathrm{A} 47 \mathrm{c} 3$ & $\mathrm{a}, \mathrm{n}, \mathrm{s}$ & $\mathrm{n}, \mathrm{s}$ & $\mathrm{n}, \mathrm{s}$ & $\mathrm{a}, \mathrm{n}, \mathrm{s}$ & $\mathrm{a}, \mathrm{n}, \mathrm{s}$ & $\mathrm{a}, \mathrm{n}, \mathrm{s}$ & $\mathrm{n}, \mathrm{s}$ & (not stim) \\
\hline IIC & $\mathrm{B} 48 \mathrm{c} 4$ & $\mathrm{a}$ & & $\mathrm{n}, \mathrm{s}$ & $\mathrm{a}, \mathrm{n}, \mathrm{s}$ & $\mathrm{n}, \mathrm{s}$ & $\mathrm{a}, \mathrm{n}, \mathrm{s}$ & $\mathrm{n}, \mathrm{s}$ & $\mathrm{a}, \mathrm{n}, \mathrm{s}$ \\
\hline IIC & $\mathrm{A} 47 \mathrm{c} 1$ & & & & $\mathrm{n}, \mathrm{s}$ & $\mathrm{n}, \mathrm{s}$ & & & \\
\hline IIC & A47c6 & $\mathrm{n}, \mathrm{s}$ & & & $\mathrm{n}, \mathrm{s}$ & & $\mathrm{n}, \mathrm{s}$ & $\mathrm{a}, \mathrm{n}, \mathrm{s}$ & $\mathrm{a}, \mathrm{n}, \mathrm{s}$ \\
\hline IIC & $\mathrm{A} 48 \mathrm{c} 13$ & & & & $\mathrm{a}, \mathrm{n}, \mathrm{s}$ & & $\mathrm{a}, \mathrm{n}, \mathrm{s}$ & $\mathrm{a}, \mathrm{n}, \mathrm{s}$ & $\mathrm{a}, \mathrm{s}$ \\
\hline IIC & B45c4 & & & & $\mathrm{a}$ & $\mathrm{a}$ & & & $\mathrm{n}, \mathrm{s}$ \\
\hline IIC & B46c4 & $\mathrm{n}, \mathrm{s}$ & & & & & & $\mathrm{a}, \mathrm{n}, \mathrm{s}$ & \\
\hline IIC & B48c14 & $\mathrm{a}, \mathrm{n}, \mathrm{s}$ & & & & & & $\mathrm{n}, \mathrm{s}$ & $\mathrm{n}$ \\
\hline
\end{tabular}

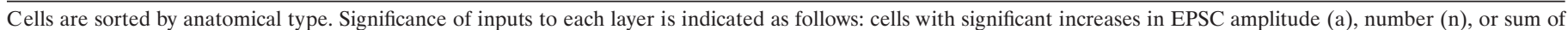

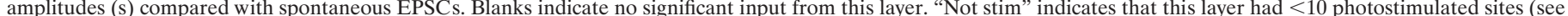

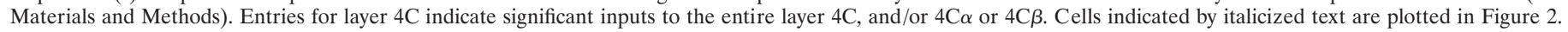

experiments using identical procedures were performed on four additional cells (data not shown), and these results agreed with those of Sawatari and Callaway (2000).

This spatial resolution allows mapping of laminar-specific excitatory input in monkey V1. Photostimulation experiments performed in parallel with those described here, using identical methods and equipment, revealed specificity of inputs from cortical layers in close proximity. These studies identified cell type specificity of inputs from layer $4 \mathrm{C} \alpha$ versus $4 \mathrm{C} \beta$ onto layer 4B neurons (Yabuta et al., 2001) and from layer $4 \mathrm{C} \beta$ onto layer 3B neurons (Sawatari and Callaway, 2000). Therefore, photostimulation is suitable for assaying laminar-specific connections in primate V1.
One exception, however, is layer 4A. Because layer 4A is typically only $\sim 50$ - to $75-\mu \mathrm{m}$-thick, photostimulation within layer $4 \mathrm{~A}$ is likely to activate neighboring neurons in layers $4 \mathrm{~B}$ or $3 \mathrm{~B}$. Additionally, only a small number of stimulation sites can be made in layer 4A. For these reasons, we rarely detected significant input from layer 4A (4 of 45 cells in our sample) (Table 1). Most cells receiving layer 4A input also received significant layer 4B input (three of four cells), and the single cell receiving layer $4 \mathrm{~A}$ but not $4 \mathrm{~B}$ input was a type that often received layer $4 \mathrm{~B}$ input (types $\mathrm{I} \alpha$ and Im; see Results). Furthermore, layer 4A contains a heterogeneous population of neurons, some of which are morphologically similar to layer $4 \mathrm{~B}$ neurons with substantial dendritic spread in layer 4B 
A

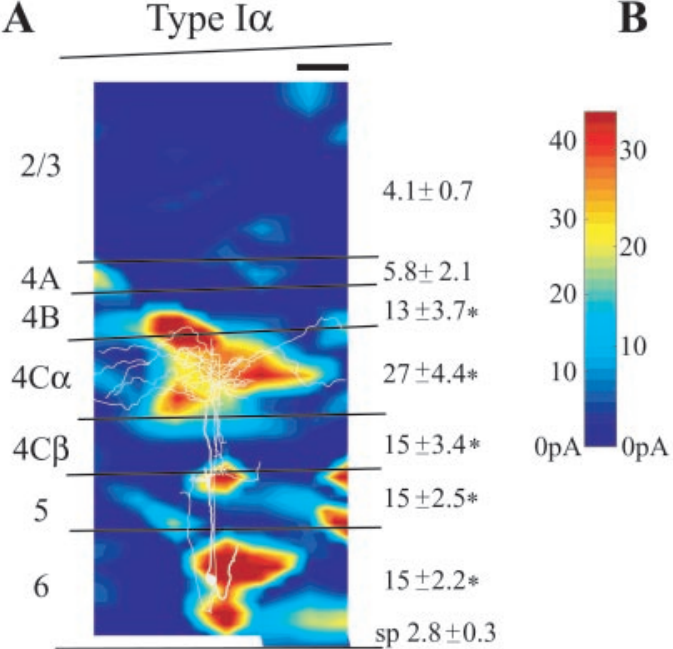

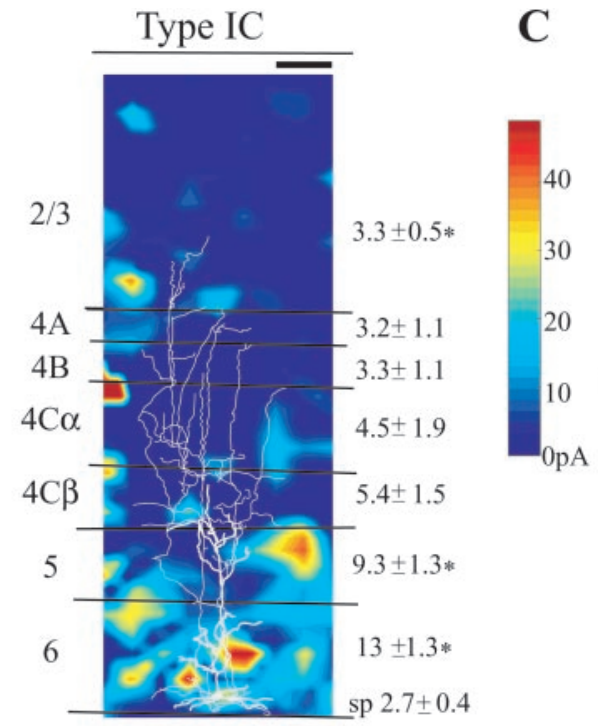

C

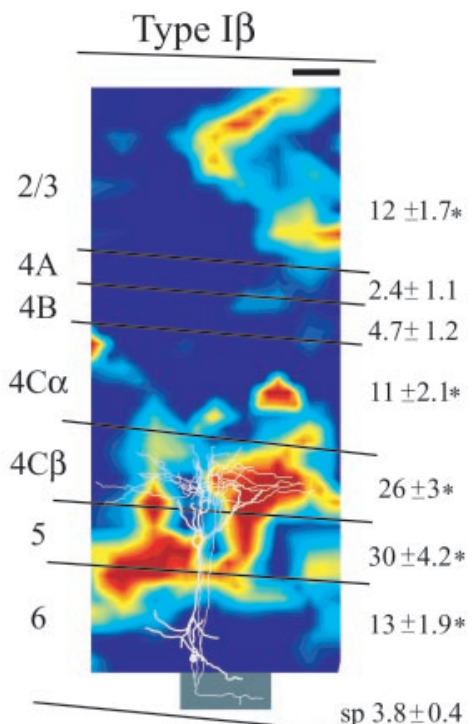

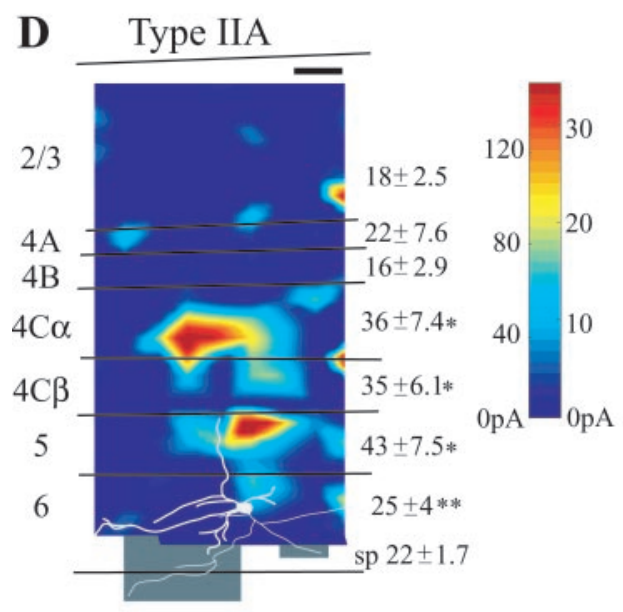

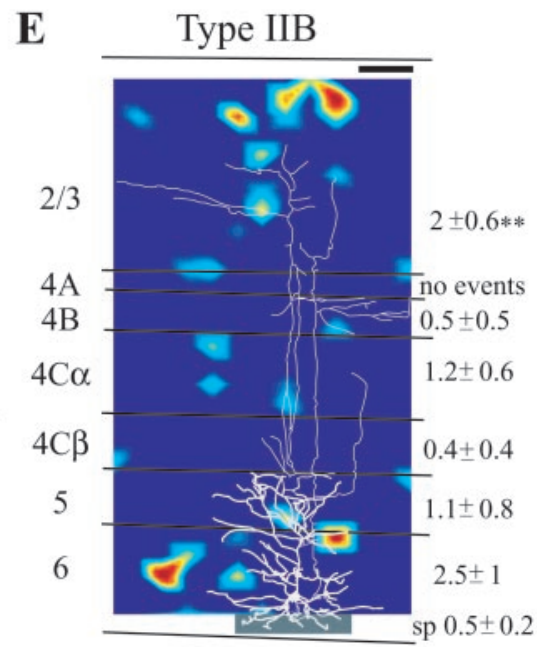

F

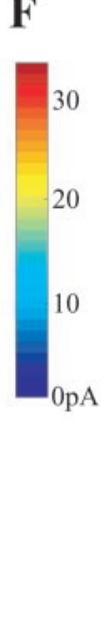

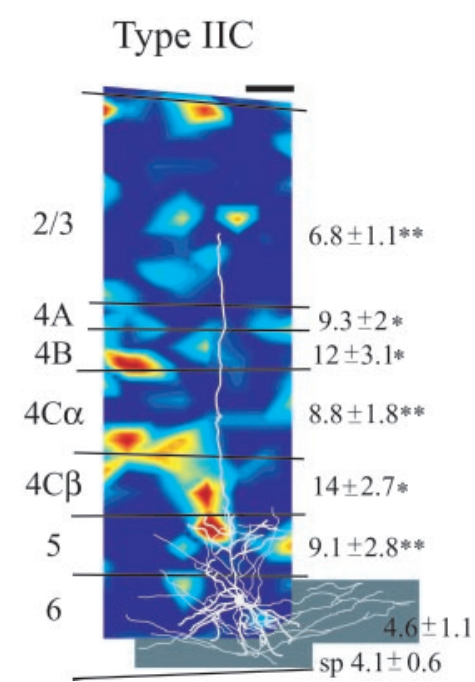

Figure 2. Functional excitatory input maps for individual class I $(A, B, C)$ and class II $(D, E, F)$ neurons. The colors at each location indicate linearly interpolated sum of EPSC amplitudes (minus spontaneous EPSCs) collected at photostimulation sites for each cell. Colors are scaled according to the scale bars between the plots. Laminar borders are represented by (near) horizontal lines and labeled to the left of the plots. Mean \pm SEM of EPSC amplitude sums (in picoamperes; spontaneous EPSCs were not subtracted out, but are shown at the bottom right of each plot) for each layer are shown to the right of each plot. Asterisks next to mean \pm SEM values indicate layers providing statistically significant input based on sum of EPSC amplitudes (single asterisk) or EPSC amplitude only (double asterisks) compared with spontaneous EPSCs. Camera lucida drawings of axons (thin white lines) and dendrites (thick) are overlaid onto plots. Gray areas are present so that neuronal processes can be seen against the otherwise white background; no photostimulation occurred within these areas. $A$, A type I $\alpha$ neuron (cell number B48c11) (Table 1 ) received significant input from layers $4 \mathrm{~B}$, 4C $\alpha$, and $4 \mathrm{C} \beta, 5$, and 6 , but not from layer $2 / 3$. B, A type IC neuron (A48c1) (Table 1 ) received significant input from layers $2 / 3,5$, and $6 . C$, A type I $\beta$ neuron (B48c2) (Table 1) received significant input from layers $2 / 3,4 \mathrm{C} \alpha$, and $4 \mathrm{C} \beta, 5$ and 6 , but not from layer 4B. $D$, A type IIA neuron (A48c12) (Table 1) received significant input from layers $4 \mathrm{C}, 5$, and 6 but not from layers above $4 \mathrm{C}$. $E$, A type IIB neuron (B45c7) (Table 1) received significant input from layer 2/3, but not from the middle layers. $F$, A type IIC neuron (A43c4) (Table 1) received significant input from layers 2/3, 4A, 4B, 4C, and 5. The axons of the type IIC neuron shown leave the plane of the slice at the layer $4 \mathrm{C} \beta / 5$ border. Scale bars, $100 \mu \mathrm{m}$ (shown at the top, right corner of each plot).

and/or axonal projections to thick stripes in V2 (Levitt et al., 1994). These observations suggest that inputs detected after stimulation in the layer 4A region may have actually originated from neurons in layer 4B or from functionally equivalent layer $4 \mathrm{~A}$ cell types. Because significant input from layer $4 \mathrm{~A}$ was rare, difficult to interpret and usually corresponded to layer $4 \mathrm{~B}$ input, it is not considered in detail in our analyses below. For the same reasons just described, photostimulation of areas at laminar borders could result in activation of neurons in the adjacent cortical layer. However, even if a photostimulated site encroached slightly into the next layer, the majority of activated cells would most likely be in the stimulated layer.

While recording EPSCs from each layer 6 neuron, hundreds of sites in each brain slice were photostimulated, allowing generation of maps of laminar locations of cells functionally connected to the layer 6 neurons
(Dantzker and Callaway, 2000; Sawatari and Callaway, 2000). Stimulation sites were located throughout a rectangular area surrounding the recorded neuron, typically extending $\sim 300 \mu \mathrm{m}$ laterally on either side of the cell and vertically from the white matter to layer 1 (Fig. 2). Stimulation trials were interspersed with no-stimulation trials to sample spontaneous EPSCs. Custom data-acquisition software digitized and recorded currents during each trial. The digitized records were analyzed to identify number and amplitudes of EPSCs occurring in each trial (Dantzker and Callaway, 2000).

After photostimulation and spontaneous-trial data were collected for an individual cell, the cell was iontophoresed with biocytin. Next, five sites of cytochrome oxidase photobleaching ( $4 \mathrm{sec}$ laser stimulation) were made adjacent to the rectangular area of stimulation sites (Dantzker and Callaway, 2000). These sites were later used to align the laminar borders 
and the anatomical reconstruction of the cell with the photostimulation sites. Slices were then fixed with $4 \%$ paraformaldehyde in $0.1 \mathrm{M}$ PBS, resectioned, and stained for cytochrome oxidase and biocytin to reveal laminar borders and neuronal morphology using methods previously described (Yabuta and Callaway, 1998a,b). After staining, labeled axonal and dendritic processes were reconstructed using a camera lucida. Sections were counterstained for thionin to visualize borders not well delineated with the cytochrome oxidase stain alone (namely the layer $4 \mathrm{C} \alpha / 4 \mathrm{C} \beta$ border and the layer 1/layer 2 border) (cf. Yabuta and Callaway, 1998b).

Each neuronal reconstruction, showing the morphology of the cell, the laminar borders, and the alignment sites, was aligned with the coordinate map of stimulation sites using Adobe Illustrator (Adobe Systems, San Jose, CA). Because the alignment sites were made in the live tissue, before fixing, sectioning, and staining, any shrinkage of the slice after those procedures was corrected by scaling the coordinate map to the reconstruction. Only linear scaling was used and invariably all five alignment sites matched the coordinate sites within $25 \mu \mathrm{m}$. Thus, any errors were small relative to the spatial resolution of the stimulation (Dantzker and Callaway, 2000, their Fig. 1).

Individual intracellular recordings were analyzed using a mini-analysis program (Synaptosoft Inc., Leonia, NJ), then grouped according to the laminar locations of stimulation sites and further analyzed for specific EPSC attributes using custom Matlab programs. The number, amplitude, and sum of amplitudes of EPSCs for each stimulation and spontaneous trial were calculated, including all events occurring within $300 \mathrm{msec}$ of the light flash. Inward currents recorded as a result of direct stimulation of the cell were easily differentiated from EPSCs and were excluded from all analyses (Dantzker and Callaway, 2000). Laminar groupings of EPSC attributes (amplitude, number, and sum of amplitudes) were compared with spontaneous EPSCs to identify statistically significant differences in EPSC amplitude, number, or sum of amplitudes using Mann-Whitney $U$ tests (Table 1). Cells were then grouped according to their morphological type (defined by Wiser and Callaway, 1996).

Two different analyses were conducted on the photostimulation data. First, comparisons between EPSC attributes from stimulation and spontaneous trials were used to determine the percentages of cells in each anatomical group that received statistically significant input from each cortical layer (Figs. $3 A, 4 A$ ). The second analysis measured the strength of laminar input. We calculated the normalized evoked input (NEI) from each layer for each cell as follows: [(average experimental sum of amplitudes) - (average spontaneous sum of amplitudes)]/(average spontaneous amplitude). Subtracting the spontaneous activity allowed for an estimate of evoked activity. Division by spontaneous EPSC amplitude normalized for variations in recording conditions between cells, such as different recording access resistances, which produced different ranges of EPSC amplitudes. These normalization procedures facilitated quantitative comparisons among cells (Dantzker and Callaway, 2000). NEIs for each layer were tabulated for cells in the same anatomical group. Significant differences in layer-specific NEIs between cell types were determined using Rank Sum Tests. In addition, we examined the locations of cells with respect to blobs in layer $2 / 3$ and whether or not cells projected axons into the white matter to assess possible correlations with functional laminar input patterns.

Disparities between the percentages of cells receiving significant laminar input and the strengths of input from the same layers were sometimes observed (see Results). In such cases, the proportion of cells receiving significant input usually suggested stronger connectivity than the corresponding NEI value. This occurred because detectable increases in EPSC amplitude were generally smaller (e.g., 20-30\%) than detectable increases in EPSC number (e.g., twofold to threefold). Thus, when significant laminar inputs were based on increased EPSC amplitude only (see Table 1), these inputs could make important contributions to the percentages of cells receiving significant input but relatively weak contributions to NEIs.

Cells with poor biocytin labeling, such that their anatomical type could not be determined, poor electrical recording access $(>50 \mathrm{M} \Omega)$, high levels of electrical noise, or $<10$ stimulation sites in any layer, were excluded from the analysis. The only exceptions were two cells that lacked sufficient stimulation sites in layer 6 because of inaccurate estimation of the white matter/layer 6 border during photostimulation. These cells were analyzed for laminar input from layers 5 and above and are indicated by "not stim" in the layer 6 column in Table 1.

To obtain clearer illustrations of input patterns for individual cells, smoothed graphs of excitatory input (linear interpolations of sum of
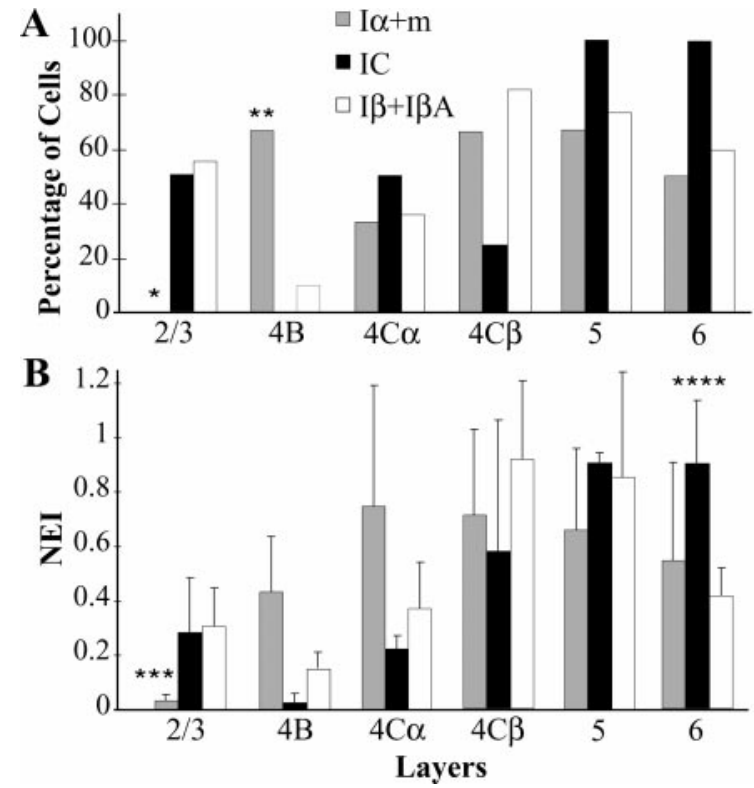

Figure 3. Laminar input to class I neurons. A, Percentages of class I neurons of each type receiving significant increases in EPSC amplitude, number, or sum of amplitudes compared with spontaneous trials for each cortical layer. *A smaller percentage of type I $\alpha$ and Im neurons received significant layer $2 / 3$ input compared with the other class I types $(p=0.03$; Fisher's Exact test). **A larger percentage of type $\mathrm{I} \alpha$ and Im neurons received significant layer $4 \mathrm{~B}$ input than the other class I types $(p=0.01)$. $B$, Mean \pm SEM of NEIs (see Materials and Methods) for each layer and for each cell type. ***Type I $\alpha$ and Im neurons received significantly weaker layer $2 / 3$ input than other class I neurons $(p=0.02$; Rank Sum test; type $\mathrm{I} \beta$ and $\mathrm{I} \beta \mathrm{A}$ vs type $\mathrm{I} \alpha$ and $\mathrm{Im}, p=0.04$; type IC vs type $\mathrm{I} \alpha$ and $\operatorname{Im}, p=0.07)$. ${ }^{* * * *}$ Type IC neurons received stronger layer 6 input than type $\mathrm{I} \beta$ and $\mathrm{I} \beta$ A neurons $(p=0.045)$. Gray bars represent type $\mathrm{I} \alpha$ and $\mathrm{Im}$ cells, black bars represent type IC cells, and open bars represent type I $\beta$ and $\mathrm{I} \beta \mathrm{A}$ neurons.

EPSC amplitude data) were generated using custom Matlab programs (Fig. 2). These plots illustrate estimated evoked activity measured in a given cell (mean sum of EPSC amplitudes for simulated trials minus mean sum of EPSC amplitudes for spontaneous trials) after stimulation at various locations.

\section{RESULTS}

Laser-scanning photostimulation was used to map laminar sources of functional excitatory input onto 45 individual pyramidal neurons in layer 6 of living brain slices from monkey V1. This method uses focal uncaging of glutamate to generate action potentials in a spatially localized population of neurons. Sources of excitatory inputs to individual neurons were mapped by recording EPSCs in single neurons while photostimulating hundreds of discrete sites. Trials measuring spontaneous activity, in which currents were recorded under identical conditions but without photostimulation, were interspersed between stimulation trials. These trials enabled the determination of sizes and frequencies of spontaneous EPSCs for each cell. We conducted two different analyses of input data for each cell. The first involved a statistical comparison between stimulated and spontaneous EPSC inputs to determine which layers provided significant input to each cell. The second analysis involved calculating the NEI to each cell to determine the strength of laminar input (see Materials and Methods).

Control experiments done during this study and in previous photostimulation studies of monkey V1 (Sawatari and Callaway, 2000; Materials and Methods) revealed that neurons fired action 

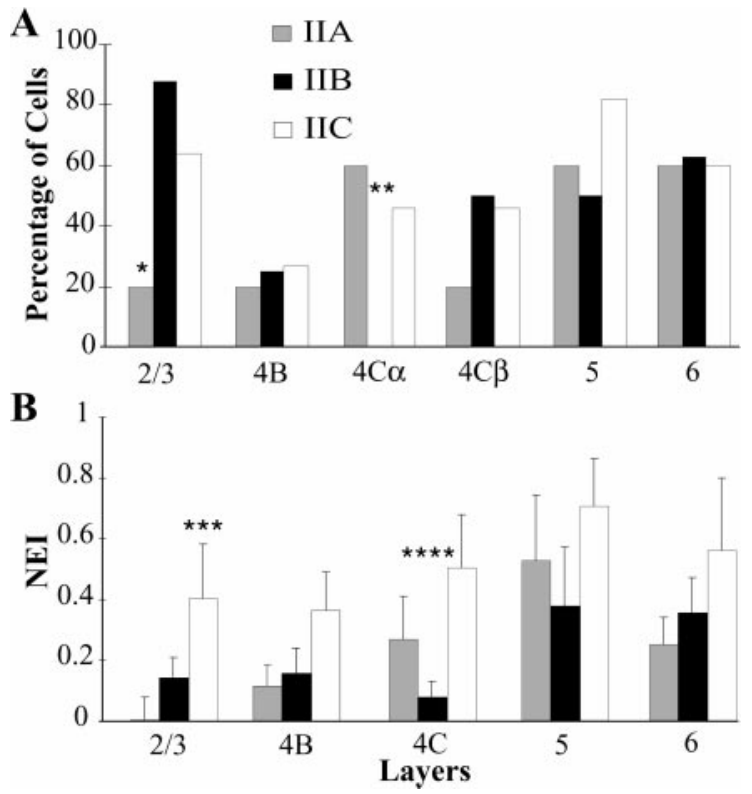

Figure 4. Laminar input to class II neurons. A, Percentage of class II neurons of each cell type receiving significant input from each layer. ${ }^{*} \mathrm{~A}$ smaller percentage of type IIA neurons received significant layer $2 / 3$ input than type IIB and IIC neurons ( $p=0.045$; Fisher's Exact test). ${ }^{* *} \mathrm{~A}$ smaller percentage type IIB neurons received significant layer $4 \mathrm{C} \alpha$ input than the other types ( $p=0.02$; IIA vs IIB, $p=0.04$; IIC vs IIB, $p=0.04$ ). $B$, Mean \pm SEM of NEIs from each cortical layer for each cell type. ***Type IIC neurons received stronger layer $2 / 3$ input than type IIA neurons ( $p=0.046$; Rank Sum test). ${ }^{* * *}$ Type IIB neurons received weaker layer $4 \mathrm{C}$ input than type IIA or IIC neurons ( $p=0.01$ for both comparisons). Gray bars represent type IIA neurons, black bars represent type IIB neurons, and open bars represent type IIC neurons. Conventions are the same as for Figure 3.

potentials only if photostimulation occurred within a $\sim 50-75 \mu \mathrm{m}$ radius of the cell body. Therefore, postsynaptic currents resulting from photostimulation reflect direct monosynaptic input from a neuron or neurons located at or near a stimulation site. Disynaptic or polysynaptic activation of a recorded neuron via neurons distant from the stimulation site would require the generation of action potentials at distant sites. The control experiments showed, however, that distant activation did not occur.

The 45 layer 6 pyramidal neurons sampled in this study included at least two of each of the previously described anatomical types: class I types $\mathrm{I} \alpha, \mathrm{Im}, \mathrm{I} \beta, \mathrm{I} \beta \mathrm{A}$, and IC and class II types IIA and IIB (Wiser and Callaway, 1996) (Fig. 1), in addition to a newly defined cell type, IIC. Although individual neurons, even within the same anatomically defined group, sometimes received different patterns of input, consistent laminar input trends were observed in certain anatomically defined groups. Anatomical features of new, more precisely defined class II cell types are first described followed by analysis of the laminar excitatory input sources to each layer 6 class I and class II cell type.

\section{Anatomy of type IIA and IIC cells}

The type IIA neurons described by Wiser and Callaway (1996) were not a distinct group but displayed diverse morphological features. During the course of this study, a third type of class II neuron was defined, separating type IIA neurons into two cell types, IIA and IIC. Two invariably correlated anatomical attributes separated type IIA from IIC cells: type IIA neurons always projected their main descending axon into the white matter and never projected local axons above layer 5, whereas type
IIC neurons never projected axons into the white matter and always above layer 5. A Fisher's Exact test indicated that these are separate populations, with the chances of misclassification being 2 in 10,000 for a cell with only one of the two parameters measured ( 0 of 5 vs 11 of 11 or 5 of 5 vs 0 of 11 cells; $p=0.0002$ ). Based on these refined definitions, five type IIA and 11 type IIC neurons were identified in this study. Figure 1 shows anatomical reconstructions of a type IIA cell (far left of bottom row) and a type IIC cell (far right of bottom row). Type IIA cells usually had cell bodies located in or near the middle of layer 6. A primary axon always projected into the white matter, and the local axons were limited entirely to layers 5 and 6 , extending laterally in the lower half of layer 6 and occasionally diagonally or vertically into layer 5. Apical dendrites of type IIA neurons could reach as high as layer $2 / 3$ with branches primarily in layers 5 and 6 and their basal dendrites were confined to lower layer 6 . In contrast, type IIC neurons had cell bodies located in the top two-thirds of layer 6. Instead of projecting into the white matter, the axons of these cells extended laterally within layers 5 and 6 , diagonally through layer 5 into layer $4 \mathrm{C}$, and columnarly as high as layer $2 / 3$. Each cell had at least one vertically or diagonally rising axon extending above layer 5. Apical dendrites of type IIC neurons could extend as far as layer $2 / 3$ and tended to branch throughout layers 5 and $6 \mathrm{~A}$. Their basal dendrites radiated below the cell body, sometimes into lower layer 6, depending on the depth of the cell body.

\section{Excitatory input to class I neurons Summary}

Photostimulation data were collected from 21 class I neurons. Class I neurons, characterized by dense axonal arbors within layer 4C, were separated into three anatomical groupings according to the sublaminar organization of their axons within layer $4 \mathrm{C}$ : type $\mathrm{I} \alpha$ and Im cells have axons in layer $4 \mathrm{C} \alpha$ only; type IC cells have axons throughout layer $4 \mathrm{C}$; and type $\mathrm{I} \beta$ and $\mathrm{I} \beta \mathrm{A}$ cells have axons in layer $4 \mathrm{C} \beta$, but not $4 \mathrm{C} \alpha$. Based on their axonal specificity for these M- or P-recipient layers, the class I cell types have been hypothesized to participate in M- or P-dominant circuits (Wiser and Callaway, 1996; Callaway, 1998). Although the present findings reveal that each class I cell type did participate differently in one or the other pathway, this difference was not manifested as distinct input from layers $4 \mathrm{C} \alpha$ or $4 \mathrm{C} \beta$, but instead from the more superficial layers. Cells with axonal arbors in layer $4 \mathrm{C} \alpha$ only (types $\mathrm{I} \alpha$ and $\mathrm{Im}$ ) (Fig. $2 A$ ) usually received significant input from layer $4 \mathrm{~B}$ but never from layer $2 / 3$. Cells with axons in layer $4 \mathrm{C} \beta$ (types IC, I $\beta$, and I $\beta$ A) (Fig. $2 B, C$ ) usually received layer $2 / 3$ input but rarely received input from layer $4 \mathrm{~B}$. Neurons from all class I cell types received input from layers $4 \mathrm{C} \alpha, 4 \mathrm{C} \beta, 5$, and 6 (Table 1). It is important to note that the input patterns represented in Figure 2 are illustrations of the laminar input sources for individual cells that are not always entirely representative of the population. For example, the type I $\alpha$ neuron in Figure $2 \mathrm{~A}$ receives stronger input from layer $4 \mathrm{C} \alpha$ than $4 \mathrm{C} \beta$, but overall, type I $\alpha$ neurons received stronger layer $4 \mathrm{C} \beta$ input (see below). There were no significant variations in input patterns among cells of the same anatomical grouping depending on either their location relative to blobs or interblobs or white matter-projection of axons. It should be noted, however, that a larger population of cells might reveal more subtle quantitative differences.

\section{Superficial layer input}

Type I $\alpha$ and Im cells never received significant input from layer $2 / 3$ ( 0 of 6 cells) compared with more than half ( 8 of 15 cells) of 
the other (type IC, I $\beta, \mathrm{I} \beta \mathrm{A})$ class I cells ( $p=0.03$ Fisher's Exact test) (Fig. 3A). Based on NEI, type $\mathrm{I} \alpha$ and Im cells received ninefold less evoked input from layer $2 / 3$ than did type $\mathrm{IC}, \mathrm{I} \beta$, and I $\beta$ A cells ( $p=0.02$; Rank Sum test) (Fig. $3 B$ ). Most type I $\alpha$ and Im cells received significant input from layer $4 \mathrm{~B}$ (4 of 6 cells) compared with only $7 \%$ ( 1 of 15 cells) of type IC, I $\beta$, and I $\beta$ A cells $(p=0.01)$ (Fig. $3 A)$. As expected based on the higher percentage of type $\mathrm{I} \alpha$ and Im cells receiving significant layer $4 \mathrm{~B}$ input, evoked layer $4 \mathrm{~B}$ input to type $\mathrm{I} \alpha$ and Im cells was fivefold stronger than layer $4 \mathrm{~B}$ input to the other class I cell types (Fig. $3 B$ ). This difference was not statistically significant because of the wide range of NEI values from layer $4 \mathrm{~B}$ onto type $\mathrm{I} \alpha$ and Im cells.

\section{Layer $4 C$ input}

In contrast to the specific excitatory input patterns from the superficial layers onto the class I types, inputs from layers $4 \mathrm{C} \alpha$ and $4 \mathrm{C} \beta$ were not cell type-specific. Similar percentages of class I cells of each type received significant input from layers $4 \mathrm{C} \alpha$ and $4 \mathrm{C} \beta$ (Fig. 3A, Table 1). Furthermore, there were no significant differences between cell types in the strengths of layer $4 \mathrm{C} \alpha$ or layer $4 \mathrm{C} \beta$ inputs based on NEIs (Fig. 3B). To examine strengths of inputs from layer $4 \mathrm{C} \alpha$ versus $4 \mathrm{C} \beta$ to each cell, we calculated ratios of NEIs from layer $4 \mathrm{C} \beta$ versus $4 \mathrm{C} \alpha$ for each neuron. There were no differences in these ratios between cell types. There was, however, an overall trend for layer $4 \mathrm{C} \beta$ input to be stronger than layer $4 \mathrm{C} \alpha$ input. Mean NEI from layer $4 \mathrm{C} \beta$ for all class I cells combined (0.79) was almost twice as large as mean NEI from layer $4 \mathrm{C} \alpha(0.45 ; p=0.046$; paired $t$ test $)$.

\section{Deep layer input}

Class I neurons from all three anatomical groupings received robust input from the deep layers 5 and 6 . High percentages of cells in each anatomical group received layer 5 input (Fig. $3 A$ ). The strengths of layer 5 inputs to different cell types were not significantly different: NEIs to type IC cells were only $40 \%$ greater than to type I $\alpha$ and Im cells and nearly equal to type I $\beta$ and $\mathrm{I} \beta \mathrm{A}$ cells (Fig. $3 B$ ). There were also no significant differences between cell types in the percentage of cells receiving significant input from layer 6. However, type IC neurons always received strong input from layer 6 (and layer 5), whereas strengths of deep layer input were more varied to the other cell types. When comparing NEIs from layer 6, type IC cells received twofold stronger input than did type $\mathrm{I} \beta$ and $\mathrm{I} \beta \mathrm{A}$ cells $(p=0.045)$ or type I $\alpha$ and Im cells (not significant).

\section{Excitatory input to class II neurons}

\section{Summary}

Photostimulation data were collected for 24 class II neurons. Layer 6 pyramidal neurons of this class tend to lack dense axonal arborizations in layer 4C and extend dendritic branches within layer 5 . Therefore, it has been suggested that these cells might receive more input from layers 5 and $2 / 3$ (pyramidal neurons in layer 2/3 project axons into layer 5; Blasdel et al., 1985; Fitzpatrick et al., 1985; Lachica et al., 1992; Callaway and Wiser, 1996) than from layer 4C. Data presented here suggest that class II cell types tend instead to receive inputs from the same layers targeted by their local axons. Type IIA cells never extend axons above layer 5 and receive the weakest inputs from superficial layers (2-4B) (Fig. 2D). Type IIB neurons receive deep layer and superficial layer inputs but weak layer $4 \mathrm{C}$ inputs, consistent with their lack of axonal arbors within layer 4C (Fig. 2E). Type IIC neurons receive inputs from all layers, consistent with their dif- fuse local axonal arbors (Fig. $2 F$ ). As with class I neurons, class II neurons did not display any apparent variations in input patterns based on locations of cells relative to blobs. (As noted above, a larger sample size could reveal subtle differences.)

\section{Superficial layer input}

A higher proportion of type IIB and IIC cells received significant input from layer 2/3 (14 of 19 cells) than did type IIA cells ( 1 of 5 cells; $p=0.045$; Fisher's Exact test) (Fig. $4 A$ ). Based on NEI, type IIC cells received $>100$-fold stronger input from layer $2 / 3$ than type IIA neurons ( $p=0.046$ ) (Fig. $4 B$ ). Type IIB cells also received 37-fold stronger layer $2 / 3$ input based on NEI than type IIA neurons (not significant) (Fig. $4 B$ ). Although type IIC neurons received threefold stronger layer $2 / 3$ input than type IIB neurons, this difference was not statistically significant (Fig. 4B). Layer $4 \mathrm{~B}$ input was detected for only $\sim 20 \%$ of class II cells, regardless of cell type (Fig. $4 A$ ). Similar to layer $2 / 3$ input, layer $4 \mathrm{~B}$ input was strongest to type IIC cells and weakest to type IIA cells, but these differences were not statistically significant (Fig. $4 B)$.

\section{Layer $4 C$ input}

No type IIB cell ( 0 of 8 cells) received significant layer $4 \mathrm{C} \alpha$ input, compared with $60 \%$ (3 of 5$)$ of type IIA cells $(p=0.04)$ and $46 \%$ (5 of 11 ) of type IIC cells ( $p=0.04$ ) (Fig. $4 A$ ). The percentages of class II cells of each type receiving layer $4 \mathrm{C} \beta$ input were not significantly different (Fig. 4A). Comparisons of NEIs from layer $4 \mathrm{C}$ onto the class II cell types revealed that both type IIA and type IIC cells received threefold stronger inputs from layer $4 \mathrm{C}$ than type IIB cells ( $p=0.01$ for both comparisons) (Fig. $4 B$ ). NEIs for layers $4 \mathrm{C} \alpha$ and $4 \mathrm{C} \beta$ were combined into a single measure for layer $4 \mathrm{C}$ (Fig. $4 B$ ) because the relative strengths of inputs from layer $4 \mathrm{C} \alpha$ versus $4 \mathrm{C} \beta$ were similar for all three types of class II cells (data not shown). [Significant layer $4 \mathrm{C} \beta$ input to type IIB neurons (Fig. 4A) was usually based solely on EPSC amplitude (Table 1) and therefore contributed only weakly to NEI (see Materials and Methods).] Although there were not cell type-specific differences in the strength of inputs from layers $4 \mathrm{C} \alpha$ or $4 \mathrm{C} \beta$, there was an overall trend for layer $4 \mathrm{C} \beta$ to provide stronger input than layer $4 \mathrm{C} \alpha$, similar to the trend for class I cells. Mean NEI from layer $4 \mathrm{C} \beta$ to all class II cells combined (0.41) was almost twice the mean NEI from layer $4 \mathrm{C} \alpha(0.24 ; p=0.076$; paired $t$ test). It is also noteworthy that these values are approximately half the corresponding values for class I cells ( 0.41 vs 0.79 for layer $4 \mathrm{C} \beta, p=0.047 ; 0.24$ vs 0.45 for layer $4 \mathrm{C} \alpha, p=0.19$ ). These differences are expected based on the differences in dendritic arborization within layer 4C (Fig. 1).

\section{Deep layer input}

Similar percentages of class II cells of each type received significant input from layer 5 (Fig. $4 A$ ), and layer 5 inputs onto cells of each type were of similar strengths (Fig. $4 B$ ). Likewise, similar percentages of cells received significant layer 6 input (Fig. 4A), and this input was similar in strength to cells of each type (Fig. $4 B)$. Although there were sometimes up to twofold differences in NEI between cell types (e.g., type IIC cells received twofold greater NEI from layer 5 than type IIB cells and twofold greater NEI from layer 6 than type IIA cells), these differences were not statistically significant.

\section{DISCUSSION}

Morphologically diverse neurons within a single cortical layer have been shown previously to receive functional excitatory input 
from different layers (Dantzker and Callaway, 2000; Sawatari and Callaway, 2000; Yabuta et al., 2001). We find that eight different types of pyramidal neurons in layer 6 of primate $\mathrm{V} 1$ also receive distinct laminar patterns of functional excitatory inputs. These input patterns were not predicted based on anatomical observations of the spatial overlap of dendrites and axons, thus demonstrating the necessity for an assay of functional connections to distinguish the specific connections and functional roles of various anatomical cell types.

We find evidence for both mixing and segregation of $\mathrm{M}$ and $\mathrm{P}$ input to class I pyramidal neurons. Although each class I cell type receives direct input from both layers $4 \mathrm{C} \alpha$ and $4 \mathrm{C} \beta$, input from the more superficial layers (2-4B) is $\mathrm{M}$ or P stream-specific. Cell type specificity of inputs therefore does not originate from the same layers $(4 \mathrm{C} \alpha$ and $4 \mathrm{C} \beta$ ) targeted by the axons of each cell type. In contrast, functional input onto class II neurons correlates with the locations of the axonal arbors of those neurons. The different input-output relationships of class I and class II neurons suggest distinct organizational principles for connectivity of these two basic cell classes.

Before discussing these results further, it is important to consider relevant limitations of the methods used. First, although photostimulation has the advantage of limiting the spatial location of cells firing action potentials to a small area around a stimulation site, stimulation probably activates all cells in that area, indiscriminant of cell type. Therefore, a significant excitatory input after stimulation in a given layer could have originated from any of the anatomically diverse excitatory cell types in that layer. We can only predict identities of cell types providing input based on our anatomical knowledge of the various cell types. Second, we must consider the possibility of false negatives. Although photostimulation may not reveal a connection, this does not absolutely exclude the possibility that cells in the stimulated area make connections onto the recorded neuron. For example, connections could have been missed because they were shunted by inhibitory inputs from the same layer or because processes were cut. Although some neuronal processes are cut during brain slice preparation, this has a minimal impact on the present studies of laminar input from within a home column (the single vertical column containing the recorded neuron). Most vertical connections between layers are not affected because in monkey V1, axons of excitatory neurons ascend or descend vertically within the plane of the brain slice before fanning out or branching laterally (Callaway and Wiser, 1996; Wiser and Callaway, 1996; Yabuta and Callaway, 1998b) (Figs. 1,2). Therefore, interlaminar connections remain intact and detectable within the radial dimension from white matter to the pial surface. In contrast, because horizontal connections are lost, we did not attempt to stimulate locations distant from the home column. Finally, the sample sizes of neurons in some cell type groupings are small. Increases in these sample sizes might reveal some smaller quantitative differences that were missed (for example laminar input patterns correlating with columnar architecture). However, because laminar input strengths varied widely between cells in the same grouping, even doubling the sample size may not reveal statistically significant differences between cell types. We feel that these data are more indicative of heterogeneity of input within cell classes rather than differences between classes.

\section{Class I neurons}

Based on their morphologies, most class I cell types are thought to play functional roles related to either $\mathrm{M}$ or $\mathrm{P}$ pathways (Lund and Boothe, 1975; Wiser and Callaway, 1996; Callaway, 1998). Type $\mathrm{I} \alpha$ and Im neurons, which project axons specifically to upper or lower layer $4 \mathrm{C} \alpha$, were expected to receive M-related inputs, whereas type I $\beta$ and I $\beta$ A neurons, which project axons to layer $4 \mathrm{C} \beta$, were expected to receive P-related inputs. Results presented here show that different types of class I neuron do receive different $\mathrm{M}$ - or P-related inputs, depending on the laminar specificity of their outputs. However, this specificity did not come from layers $4 \mathrm{C} \alpha$ and $4 \mathrm{C} \beta$. Instead, class I neurons received unique inputs from the superficial layers targeted by layers $4 \mathrm{C} \alpha$ and $4 \mathrm{C} \beta$. M-dominated layer $4 \mathrm{~B}$ provided input onto neurons with axons limited to layer $4 \mathrm{C} \alpha$ (types $\mathrm{I} \alpha$ and Im). P-dominated layer $2 / 3$ provided input onto neurons with axons in layer $4 \mathrm{C} \beta$ (types IC, I $\beta$, and I $\beta A$ ). Surprisingly, class I neurons tended to receive similar layer $4 \mathrm{C} \alpha$ and $4 \mathrm{C} \beta$ input regardless of cell type. In light of the fact that class I neurons lack dendrites in lower layer 5 , it was also surprising that all class I cell types received robust input from layer 5 (Callaway and Wiser, 1996; Wiser and Callaway, 1996). All class I cell types also received input from layer 6 , which contains the densest dendritic arborizations of these cells.

\section{Thalamocortical inputs to class I neurons}

The function of each layer 6 cell type is dependent not only on its local V1 inputs, but also on input from the LGN. Anatomical observations suggest that direct LGN input onto the class I cell types is functional stream-specific. LGN afferents project to the main recipient layers $4 \mathrm{C} \alpha$ and $4 \mathrm{C} \beta$, where each class I cell type could receive $\mathrm{P}$ - or $\mathrm{M}$-specific inputs onto their layer-specific apical dendritic arbors. Thalamocortical afferents also tend to project preferentially to lower ( $\mathrm{M}$ input) versus upper ( $\mathrm{P}$ input) layer 6 (Hendrickson et al., 1978; Blasdel and Lund, 1983) where they might target type $\mathrm{I} \alpha$ and Im cells versus type $\mathrm{I} \beta$ and I $\beta \mathrm{A}$ cells, respectively. Although any thalamocortical input onto apical dendrites must be specific, it is possible that there is mixing of $\mathrm{M}$ and $\mathrm{P}$ LGN afferent inputs onto basal dendrites, which are in positions to sample input from both streams.

\section{Functional implications of specific input patterns to class \\ I cells}

Class I neurons receive $\mathrm{M}$ or $\mathrm{P}$ stream-specific inputs from the same superficial cortical layers $(2 / 3$ and $4 \mathrm{~B})$ whose neurons project to extrastriate cortical areas in the dorsal and ventral streams, respectively (for review, see Livingstone and Hubel, 1988; Merigan and Maunsell, 1993). This input specificity correlates with selective axonal targeting of class I cell types for $\mathrm{M}$ recipient layer $4 \mathrm{C} \alpha$ or $\mathrm{P}$ recipient layer $4 \mathrm{C} \beta$. Thus, class I neurons are sampling copies of $\mathrm{M}$ - or P-related information that will be sent on to higher visual cortical areas. In turn, class I neurons send their axons specifically to layers $4 \mathrm{C} \alpha$ or $4 \mathrm{C} \beta$, presumably to modify the inputs of these layers to their superficial target layers. These correlations suggest that an important role of class I neurons in layer 6 is to modify input to the superficial neurons based on sampling of their outputs.

Whereas all class I neurons may be performing similar functions, there are differences in the patterns of connectivity for different cell types. $\mathrm{M}$ pathway-related type $\mathrm{I} \alpha$ and Im neurons never project axons into the white matter (Wiser and Callaway, 1996) (Table 1) and therefore cannot provide any feedback to the LGN. All layer $4 \mathrm{C} \beta$-projecting cell types (types I $\beta$, I $\beta$ A, and IC) can project out of V1, presumably back to the LGN P layers (type $\mathrm{I} \beta$ and $\mathrm{I} \beta \mathrm{A}$ cells) or $\mathrm{M}$ and $\mathrm{P}$ layers (type IC cells; Fitzpatrick et al., 1994; Wiser and Callaway, 1996). Thus, the M pathway may 
use predominantly local V1 circuits to modify pathway-specific activity, whereas the $\mathrm{P}$ pathway may use local and corticogeniculate circuitry. These observations suggest that the circuitry involving type $\mathrm{I} \alpha$ and Im cells and layer $4 \mathrm{C} \alpha$ may operate differently than the corresponding $\mathrm{P}$ pathway circuitry. Perhaps faster modulation is achieved in the $\mathrm{M}$ pathway by using only local connections and fewer synapses. This could be important for the $\mathrm{M}$ pathway to process motion information at high temporal frequencies. The $\mathrm{P}$ pathway, more concerned with visual acuity and form, may benefit from an additional corticothalamic loop.

\section{Class II neurons}

\section{Anatomy of type IIA and IIC cells}

During the course of examining the anatomical features of layer 6 pyramidal neurons in this study, it became apparent that the previously described type IIA category (Wiser and Callaway, 1996) actually included two morphologically distinct types of class II neurons. Type IIA neurons were more precisely defined as projecting axons into the white matter and having local axons exclusively within the deepest layers. These cells tend to be located in the middle of layer 6 and to have long, laterally projecting axons within layer 6 . Type IIC neurons have only local axons which project diagonally and columnarly into layer $2 / 3$. The cell bodies of type IIC neurons tend to be located mostly in the upper half of layer 6 . We are confident that type IIA and IIC neurons are indeed two distinct cell types since the two defining characteristics of these cells (white matter projecting or not and local axons above layer 5 or not) are binary criteria and invariably correspond.

\section{Inputs to class II cells}

Class II neurons, all of which have dense dendritic arbors in layer 5, were expected, based on anatomical observations, to receive inputs from layers $2 / 3$ and 5 . Results presented in this study show, however, that the best predictor of laminar input onto the class II cell types is the laminar organization of their axonal, not dendritic, arbors. Type IIA cells lack axons above layer 5 and receive only very weak input from the superficial layers. Type IIB cells arborize in the deepest and most superficial layers, but not layer $4 \mathrm{C}$ and receive inputs from the same layers. Type IIC neurons arborize throughout all cortical layers and receive corresponding diffuse inputs. These observations suggest that class II cells participate in more direct interactions than class I cells, modifying the input-output of the same neurons that provide their inputs.

\section{REFERENCES}

Blasdel GG, Lund JS (1983) Termination of afferent axons in macaque striate cortex. J Neurosci 3:1389-1413.

Blasdel GG, Lund JS, Fitzpatrick D (1985) Intrinsic connections of macaque striate cortex: axonal projections of cells outside lamina 4C. J Neurosci 5:3350-3369.

Callaway EM (1998) Local circuits in primary visual cortex of the macaque monkey. Annu Rev Neurosci 21:47-74.

Callaway EM, Katz LC (1993) Photostimulation using caged glutamate reveals functional circuitry in living brain slices. Proc Natl Acad Sci USA 90:7661-7665.

Callaway EM, Wiser AK (1996) Contributions of individual layer 2-5 spiny neurons to local circuits in macaque primary visual cortex. Vis Neurosci 13:907-922.

Dantzker JL, Callaway EM (2000) Laminar sources of synaptic input to cortical inhibitory interneurons and pyramidal neurons. Nature Neurosci 3:701-707.

Fitzpatrick D, Lund JS, Blasdel GG (1985) Intrinsic connections of macaque striate cortex: afferent and efferent connections of lamina 4C. J Neurosci 5:3329-3349.

Fitzpatrick D, Usrey WM, Schofield BR, Einstein G (1994) The sublaminar organization of corticogeniculate neurons in layer 6 of macaque striate cortex. Vis Neurosci 11:307-315.

Hawken MJ, Parker AJ, Lund JS (1988) Laminar organization and contrast sensitivity of direction-selective cells in the striate cortex of the Old World monkey. J Neurosci 8:3541-3548.

Hendrickson AE, Wilson JR, Ogren MP (1978) The neuroanatomical organization of pathways between the dorsal lateral geniculate nucleus and visual cortex in Old World and New World primates. J Comp Neurol 182:123-136.

Hubel DH, Wiesel TN (1968) Receptive fields and functional architecture of monkey striate cortex. J Physiol (Lond) 195:215-243.

Katz LC, Dalva MB (1994) Scanning laser photostimulation: a new approach for analyzing brain circuits. J Neurosci Methods 54:205-218.

Lachica EA, Beck PD, Casagrande VA (1992) Parallel pathways in macaque monkey striate cortex: anatomically defined columns in layer 3. Proc Natl Acad Sci USA 89:3566-3570.

Levitt JB, Yoshioka T, Lund JS (1994) Intrinsic cortical connections in macaque visual area V2: evidence for interaction between different functional streams. J Comp Neurol 342:551-570.

Livingstone M, Hubel DH (1988) Segregation of form, color, movement, and depth: anatomy, physiology, and perception. Science 240:740-749.

Lund JS, Boothe RG (1975) Interlaminar connections and pyramidal neuron organization in the visual cortex, area 17 , of the macaque monkey. J Comp Neurol 159:305-334.

Merigan WH, Maunsell JHR (1993) How parallel are the visual pathways? Annu Rev Neurosci 16:369-402.

Sawatari A, Callaway EM (1996) Convergence of magno- and parvocellular pathways in layer $4 \mathrm{~B}$ of macaque primary visual cortex. Nature 380:442-446.

Sawatari A, Callaway EM (2000) Diversity and cell type specificity of local excitatory connections to neurons in layer 3B of monkey primary visual cortex. Neuron 25:459-471.

Wiser AK, Callaway EM (1996) Contributions of individual layer 6 pyramidal neurons to local circuitry in macaque primary visual cortex. J Neurosci 16:2724-2739.

Wiser AK, Callaway EM (1997) Ocular dominance columns and local projections of layer 6 pyramidal neurons in macaque primary visual cortex. Vis Neurosci 14:241-251.

Yabuta NH, Callaway EM (1998a) Cytochrome-oxidase blobs and intrinsic horizontal connections of layer $2 / 3$ pyramidal neurons in primate V1. Vis Neurosci 15:1007-1027.

Yabuta NH, Callaway EM (1998b) Functional streams and local connections of layer $4 \mathrm{C}$ neurons in primary visual cortex of the macaque monkey. J Neurosci 18:9489-9499.

Yabuta NH, Sawatari S, Callaway EM (2001) Two functional channels from primary visual cortex to dorsal visual cortical areas. Science, in press.

Yoshioka T, Levitt JB, Lund JS (1994) Independence and merger of thalamocortical channels within macaque monkey primary visual cortex: anatomy of interlaminar projections. Vis Neurosci 11:467-489. 